\title{
PENDAMPINGAN ASSESSMENT PEMBELAJARAN TERINTEGRASI DI PONDOK PESANTREN BAHRUL MAGHFIROH KOTA MALANG
}

\author{
Ibnu Mujib ${ }^{1)}$, Jazuli $^{2)}$, Riyanto ${ }^{3)}$, Susandi ${ }^{4)}$, Trio Ageng Prayitno ${ }^{5)}$ \\ IKIP Budi Utomo \\ ${ }^{1)}$ Ibnumujib19@gmail.com, ${ }^{2)}$ jasuli@budiutomomalang.ac.id, ${ }^{3)}$ riyanto@budiutomomalang.ac.id, \\ ${ }^{4)}$ susandi@budiutomomalang.ac.id, ${ }^{5)}$ trioagengprayitno@budiutomomalang.ac.id
}

\begin{abstract}
This assessment is carried out to evaluate the learning process by emphasizing aspects of the integrated curriculum developed at the Bahrul Maghfiroh Islamic Boarding School. This process, which at every stage of its history has always undergone changes and dynamic cycles, must receive serious attention. The issue of curriculum since the implementation of the merger between the boarding school curriculum and the general school curriculum to this day is still a long debate, especially how the pesantren curriculum, which was originally oriented to ansih Islamic boarding school, must accommodate the general curriculum which is actually far from the experience expected by previous pesantren. This assessment is carried out with a grounded approach by conducting sufficient interviews, distributing questionnaires, and tracking school or boarding documents and followed by focus group discussions (FGD).

At the implementation level, the curriculum merger effort at the Bahrul Maghfiroh Islamic Boarding School in Malang City is still limited to improving the school or class schedule, which means that on the improvement side at the level of material or certain fields of study, it is still in the process of improving and discussing discussions by coordinating continuously and thoroughly. In addition, at this stage the supporting laboratories are almost 70 percent completed to adjust to global needs which will be used and utilized by students in the future. The fields of agriculture, animal husbandry, and student entrepreneurship, and small industrial industries, in the future will become laboratories, not only for the sake of an integrated curriculum but also in general the vision of this pesantren, including strengthening the capacity of relevant learning media, but also upgrading Islamic boarding school human resources, so that they are able to synergize with digital speed which is the key in the era of the industrial revolution 4.0, currently the Bahrul Maghfiroh Islamic Boarding School is preparing
\end{abstract}

Keywords: Pembelajaran, pondok pesantren, sekolah umum, kurikulum terintegrasi, evaluasi

\section{ANALISIS SITUASI}

Pembelajaran di pesantren merupakan suatu proses pembelajaran yang unik, terutama dalam membangun karakter (character building) seorang santri. Santri digembleng sedemikian rupa untuk menguatkan sikap-sikap keteladanan sosial dan religiusitas. Sebagaimana digambarkan oleh Abdurahman wahid, bahwa sistem nilai yang tumbuh di dalam pesantren memiiki kekhasan tersendiri, setidaknya ada tiga nilai yang tak bisa dilepaskan dalam mendiskusikan persoalan nilai di pesantren. Pertama, persoalan cara menilai keseluruhan aspek kehidupan sebagai ibadah, kedua. Perhatian yang mendalam pada aspek ilmuilmu agama, ketiga. Memiliki komitmen yang tinggi pada pekerjaan yang berorientasi pada tujuan-tujuan bersama (wahid,2009). Ketiga bentuk nilai dasar ini patut menjadi renungan 
bersama terutama dalam membentuk karakter santri atau siswa di sekolah. Oleh karena itu, orientasi pada pembelajaran karakter menjadi poin substansial dalam proses pembelajaran dan pembentukan kurikulum, tidak saja di pesantren sendiri tetapi juga di sekolahsekolah umum.

Jika kita lihat tahapan-tahapan perubahan kurikulum selama ini, setidaknya pasca reformasi di Indonesia sudah mengalami 3-4 kali perubahan kurikulum. Setidaknya sejak tahun 2002/2004 (Kurikulum Berbasis Kompetensi) dan tahun 2006 (Kurikulum Tingkat Satuan Pendidikan). Perubahan tersebut merupakan konsekuensi dan implikasi dari terjadinya perubahan sistem politik, sosial budaya, ekonomi, dan perkembangan IPTEK (Ilmu Pengetahuan dan Teknologi) di Indonesia. Dan setelah itu yang terahir kurikulum K 13, kurikulum ini lah beberapa ahli menyetakan sebagai peletak pertama yang mempertimbangkan wacana pembangunan karekter dengan ditandai dimulainya sistem kurikulum terintegrasi untuk merespon dunia yang cepat berubah.

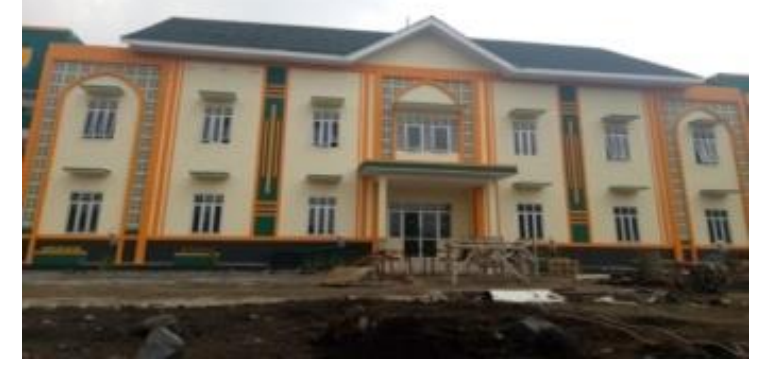

Gambar 1. Pondok Pesantren Bahrul Maghfiroh

Melalui dasar perubahan itulah sebagai alasan diubahnya kurikulum tingkat satuan pendididkan (KTSP) menjadi "kurikulum 2013". Salah satu alasan perubahan ini diantaranya terjadi karena capaian visi kompetensi peserta didik masih dinilai lemah dalam orientasi pembentukan karakter siswa. Oleh karena itu, ditawarkannya kurikulum 2013 merupakan bagian dari upaya penyempurnaan dari sistem kurikulum sebelumnya, sehingga sekurangkurangnya kurikulum 2013 dinilai telah mencakup kompetensi sikap, pengetahuan dan ketrampilan secara terpadu. Sebagaimana konsep yang dicita citakan dalam konstruksi kurikulum 2013 adalah untuk mencetak generasi muda yang memiliki kompetensi secara komprehensi, tidak saja mengolah kecerdasan intelektual, melainkan juga kecerdasan sosial dan spiritualnya. Hal ini bisa kita amati pada terinteegrasikannya nilainilai karakter dalam proses pembelajaran, bukan lagi tampak hanya sebagai suplemen dalam pembelajaran, sebagaimana kurikulum sebelumnya.

Salah satu alasan menguatnya dorongan publik sekolah untuk menggunakan kurikulum 13 adalah karena dunia pendidikan dinilai gagal dalam mentransformasi bangunan karakter peserta didiknya. Bahkan ditengah perdebatan penyusunan kurikulum sekolah, wacana atau praktik marger atau upaya mengakomodasi model kurikulum terintegrasi (pesantren ke sekolah umum, dan begitu sebaliknya dari kurikulum sekolah ke pesantren) merupakan wacana mayor dalam pengelolaan pendidikan kita. Sehingga bagi yang semula lembaga pendidikanya dikelola dengan sistem pondok pesantren, maka didalamnya harus dikuatkan dengan kontek materi-materi ilmu-ilmu umum, begitu sebaliknya bagi lembaga pendidikannya yang semula dikelola dengan sistem sekolah, maka didalamnya harus dikuatkan dengan sistem pesantren. Begitulah sistem marger kurikulum kita yang selama ini berjalan. Dengan demikian masing-masing lembaga harus mempu saling mengakomodasi kurikulum baik yang dari pesantren maupun sekolah, 
baik dengan menggunakan integrasi pada konten bidang pelajaran, metode, maupun terintegrasi melalui sistem atau pola-pola pembelajaran yang diharapkan.

Sejak dilakukannya inisiatif merger kurikulum atau disebut kurikulum terintegrasi ini, masing-masing dengan kekuatan dan kapital serta basis yang dimiliki sebelumnya tampak dari masing-masing masih saling beradaptasi secara terus-menerus. Mereka yang dari pondok harus beradaptasi dengan kurikulum baru yang terintegrated seperti bidang ajar matematika, fisika, biologi dan lain sebagainya. Tentu tidak saja menyiapkan materi dan metode pembelajaran yang relevan, atau bahkan media pembelajaran yang kompetibel dengan perkembangan jaman, akan tetapi pesantren juga dituntut menyelesaikan problem-problem SDM guru yang dalam pemenuhannya tidak semudah membalikkan telapan tangan bagi pesantren. Selain perlu waktu yang tidak sedikit, juga bagi pesantren tentu akan mengurangi beban kegiatan-kegiatan pesantren yang selama ini hampir sudah menjadi pakem keseharian. Konsekuansi itu semua juga berlaku bagi sekolah umum yang juga dituntut selaras menyesuaikan kurikulum pesantren dan ini juga bukan sesuatu yang mudah bagi sekolahsekolah umum untuk mengakomodasi polapola pesantren.

Pertanyaan yang masih tersisa hingga hari ini adalah sudahkah kompetible kurikulum terintegrasi ini, baik bagi sekolah maupun bagi pondok pesantren, bagaimana proses pembelajaran yang dilakukan selama ini?, adakah dampak yang signifikan bagi santri ataupun guru dan seperti apa pengaruhnya?, pertanyaan selanjutnya bagaimana keterlibtan para santri dalam mengimbangi proses pembelajaran di kelas, termasuk didalamnya menyengkut metode, media sampai kesiapan SDM. Assessment ini akan menggambarkan dengan mengevaluassi beberapa pertanyan di atas untuk menata kembali konsep-konsep pembelajaran beserta kurikulumnya yang lebih relevan dan memenuhi substansi yang komprehensif bagi pesantren kedepan.

\section{METODE PELAKSANAAN}

Sebagai langkah awal dari pendampingan pembelajaran berbasis kurikulum terintegrasi, strategi penyusunan Assesemnt ini dilakukan dengan menggunakan metode perticipatory need assaassment yang dikuatkan dengan metode grounded yakni berbasis kualitatif yang dikolaborasi dengan kuantitatif agar lebih memudahkan dalam skala dan ukuran capainnya. Pendekatan (grounded theoritical approach) dalam pengambilan data dengan melakukan observasi sekaligus depth interview pada subjek-subjek yang berpengaruh, seperti bagian atau waka bidang kurikulum, para guru atau ustadz dan para santri pondok. Kedua, selain beberapa subjek di interview, perlunya dilakukan penyebaran angket, beberapa model angkat akan kita sebar ke para guru maupun santri. Ketiga, pengambilan data juga dilakukan dengan pelacakan dokumen sekolah ataupun pondok. Keempat. Dan yang keempat diikuti kegiatan diskusi kelompok terfakus (FGD). FGD ini dilakukan untuk memperoleh data yang sifatnya lebih terbuka dan mengandung unsur representasi-representasi tertentu, baik kelembagaan maupun ditingkat perorangan.

\section{HASIL DAN PEMBAHASAN}

Pada bagian ini assessment dilakukan di dua angkatan sekolah sekaligus yaitu SMP dan SMA di pondok ini, namun dalam penjelasan laporan ini kami gambarkan secara lebih fokus yaitu bagaimana implementasi kurikulum terintegrasi tersebut di lakaukan di 
tingkat SMA. Pembatasan ini dilakuan agar penjelasan mengenai implementasi kurikulum terintegrasi ini dapat disampaikan secara lebih terperinci dan komprehensif. Selain memang secara representasional pembatasan ini juga dianggap cukup mewakili karena telah mewakili kebijakan yayasan pondok pesantren secara umum.

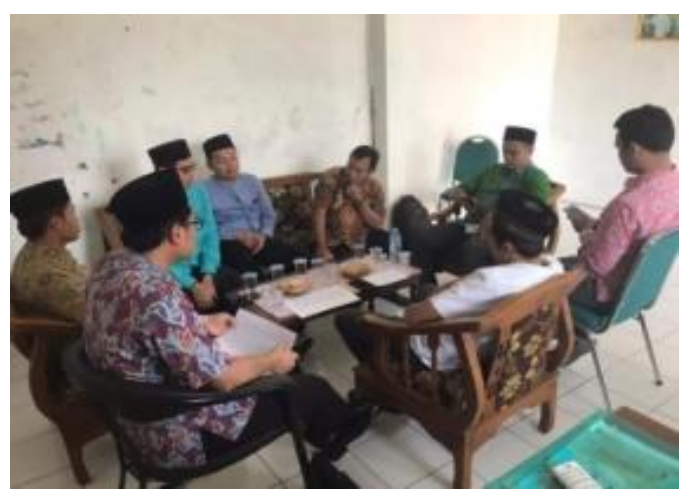

Gambar 2. Kunjungan tim pengabdi ke pimpinan pondok Bahrul Maghfiroh.

Pondok pesantren Bahrul Maghfiroh merupakan salah satu pesantren di Indonesia yang juga turut mendesain kurikulumnya dengan pola integrasi. Sekolah yang berada di pondok pesantren ini juga sedang menjajaki kurikulumnya secara terintegrasi sebagaimana kelompok sekolah yang ada dalam payung SBP (Sekolah Berbasis Pesantren). Meskipun implementasinya baru berlangsung 3 sampai 4 bulan pada saat assessment ini di lakukan.

Ada bebrapa poin yang menjadi catatan dalam pelaksanaan assessment kurikulum di pondok almaghfirah ini yaitu, pembelajaran di kelas dan manajemen sekolah,. Di bawah ini akan kami uraikan beberapa poin tersebut.

A. Menganalisa Pembelajaran di Kelas

Menyoal pembelajaran di kelas tidak bisa dilepaskan dari pengamatan para guru ataupun siswa sendiri di kelas kelas. Keterlibatan siswa menjadi penting, karena merupakan subjek yang paling memiliki otoritas dalam memerankan proses pembelajaran adalah siswa atau santri dalam konteks pesantren. Jika kita amati beberapa proses pembeljaran di pondok baik sebelum ataupun sedang menggunakan kurikulum terintegrasi, peran serta siswa tidak biasa diabaikan begitu saja, karena aspek keragaman siswa dalam kelas membutuhkan analisa tersendiri, untuk itu pembelajaran bukanlah suatu proses yang bisa dikendalikan seperti membalikkan telapak tangan. Oleh karena itu dalam proses pembelajaran di kelas melibatkan pertimbangan-pertimbangan matang mengenai diri siswa dan kesiapankesiapan menjalankan proses pembelajaran merupakan aspek terpenting dari aspek lainya seperti sdm guru ataupun kurikulum.

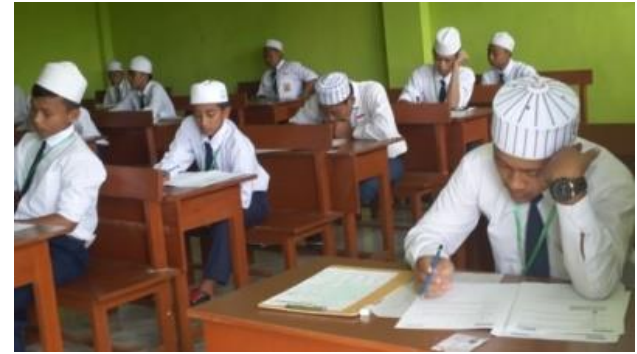

Gambar 3. Proses pembelajaran santri pondok Bahrul Maghfiroh

Sebagai pesantren yang masih menggunakan pendekatan tradisional, Pesantren Bahrul Magfirah kini juga dituntut memliki manajemen yang standar dalam melakukan pembelajaran di sekolah, mulai dari aspek SDM guru, kurikulum, mekanisme waktu, manajemen pembelajaran, metode sampai media pembejaranya dituntut mengikuti pola dengan sistem sekolah moderen atau umum. Oleh karena itu suatu upaya serius dan penuh perjuangan tersendiri yang harus dilakukan di pesantren ini.

Pada dasarnya sekolah berbasis pondok pesantren yang dilakukan di pondok ini sudah lama yaitu sejak 2019 akhir dilakukan. Sistem pembelajaran yang diterapkan tentunya masih mengunakan pendekatan tradisional sebagaimana 
pendekatan yang dilakukan di pesantren sendiri, hanya pola pembelajaran yang mereka lakukan sedikit banyak juga mengadopsi sistem pembelajaran di sekolah sekolah umum. Ini bagi pesantren merupakan upaya terbuka dengan instansi di luar pondok pesantren. Indikator paling mudah ditandai dalam suatu proses integrasi kurikulum adalah menghilangkan batas batas antar-mata pelajaran dan memberikan bahan pelajaran melalui unit unit yang saling tumpang tindih sebagai orientasi kajiannya. Suatu contoh seorang guru mata pelajaran umum diharapkan tidak saja menyampaikan pelajaran sebatas materi teks seperti tertulis di buku, malainkan mampu memkontektulisasikannnya ke dalam fakta fakta sosial yang ada di masyarakat dengan misalnya menyelipkan nilai-nilai agama.

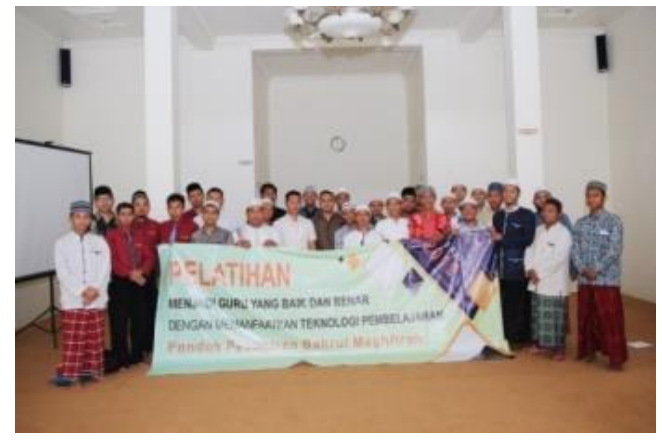

Gambar 4. Tim Pengaabdi bersama santri

Sisi lain pesantren yang memeliki kegiatan pembelajaran berbasis sekolah seyogyanya banyak melakukan adaptasi pola pembelajaran yang berlangsung di sekolah umum. Karena pola pembelajaran di sekolah umum sudah memiliki standar pengelolaan berdasarkan tinjauan kebijakan terstruktur dan telah mengalami perubahan -perubahan sistem sebagai dasar dari pengalaman pengelolaan.
B. Pendampingan Strategis Sistem Kurikulum Terintegrasi

1. Mengevaluasi Kebijakan Sekolah dan Pondok

Pengelolaan sekolah berbasis pondok (SBP) di Pesantren Bahrul Maghfiroh menggunakan sistem kurikulum terintegrasi. Kebijakan ini dilakukan untuk mengikuti perkembangan pengelolaan sekolah yang berada dalam manajamen pondok pesantren. Para elit pondok bersepakat bahwa sekolah baik di tingkat SMP maupun SMA harus mengikuti sistem kurikulum terintegrasi, ini artinya seluruh komponen kurikulum sekolah diselaraskan dengan menggunakan sistem terintegrasi, baik pada aspek materi maupun waktu. Artinya ide dasar sistem terintegrasi musti dihadirrkan dalam proses belajar dan mengajar di sekolah. Penanaman nilai-nilai keagamaan dalam materi sekolah umum harus dihadirkan secara inten dalam proses pembelajaran, begitu sebaliknya penanaman muatan umum juga dilekatkan dalam pengajaran materi materi keagamaan.

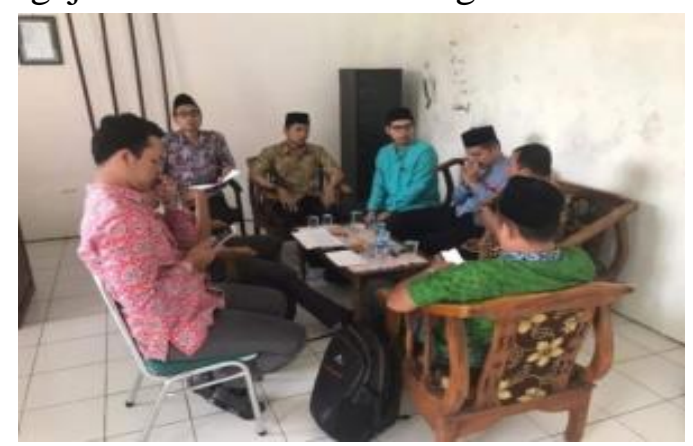

Gambar 5. Tim pengabdi dan pimpinan pondok

Menurut penuturan beberapa pengelola sekolah di pesantren Bahrul Maghfiroh sistem yang diikuti dan diterapkan dalam proses pembelajaran di sekolah masih tahap adaptasi, sehingga mengikuti aturan sistem terintegrasi di sekolah masih sebatas pengelolaan waktu atau jam pelaran. Bagi 
sekolah di dalam komunitas pondok menerapkan sistem terintegrasi memang bukan hal yang mudah dilakukan, karena harus membutuhkan adaptasi panjang, baik hal yang berkaitan dengan sistem pemebelajaran di pondok secara umum, waktu yang harus menyesuasikan tata aturan pondok yang sudah berlangsung lama di pondok, maupun perubahan pendekatan pembelajaran yang harus mengikuti tata aturan sistem terintegrasi itu sendiri.

Oleh karena itu tidak heran jika dalam beberapa bulan berjalan implementasi sistem terintegrasi di pondok masih sebatas pengelolaan integrasi waktu antara waktu di pondok dan di sekolah. Sementara pengelolaan yang bebasis pada materi pembelajaran masih belum sama sekalai dijalankan. Karena selain keterbatasan SDM yang ada, juga dibutuhkan pengawalan yang ketat mengenai proses pembelajaran dengan sistem terintegrasi. Salah satu pengurus sekolah menjelaskan bahwa "jika diikuti dengan benar sistem terintegrasi ini mungkin akan manghasilkan suatu produk yang sangat bagus dan membanggakan, akan tetapi hal ini sangat membutuhkan proses yang relatif panjang, tenaga yang cukup, SDM yang kompatible, serta membutuhkan koordinasi yang intens dan terus menerus terutama dalam merespon perkembangan pengelolaan model kurikulum terintegrasi seperti ini.

\section{Memberdayakan Sistem Koordinasi Antar Unit Sekolah Dan Pondok}

Untuk menjembatani

implementasi kurikulum terintgrasi berlangsuung dengan baik, maka salah satu unsur yang penting diperhatikan adalah sistem kordinasi antar unit sekolah, baik santri, guru, bagian kurikulum dan kepala sekolah dalam hal ini mewakili lembaga/ manajemen sekolah. Interaksi koordinatif antara empat unit penting ini merupakan kata kunci berjalannya sebuah program yang dicitacitakan sekolah, dalam hal ini proses implementasi atau pelaksanaan kurikulum terintegrasi di pondok.

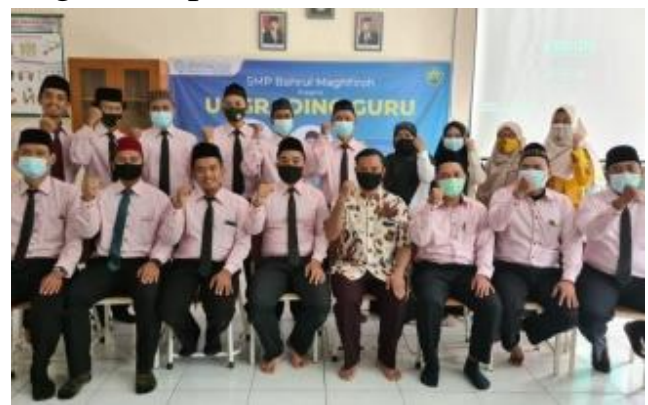

Gambar 6. Tim Pengajar Pondok bahrul Maghfiroh

Dalam sebuah pengawalan program yang demikian rumit ini memang dituntut agar sekolah memiliki agenda kordinasi antar unit sekolah yang cukup intens. Karena di dalam program ini mengandung unsur pembentukan sistem dan budaya baru di sekolah. Apalagi sekolah yang dimaksud memiliki basis pondok yang tentunya sangat kuat akan ikut mengkonstruksi pilar-pilar atau konsepsi tentang sistem integrasi kurikulum yang diinginkan. Oleh karena itu, koordinasi selain yang berhubungan dengan aspek pengelolaan kurikulum, kesiapan para SDM guru/ustadz, dan penyamaan persepsi di anatara para pengendali program dalam hal ini konsolidasi antar unit sekolah, juga kematangan dalam menyusun orientasi kurikulum terintegrasi sebagaimana yang dikonsepsikan pihak pengembil kebijakan sekolah.

Keseluruhan proses koordinasi diatas tentunya pelan tapi pasti akan menumbuhkan serta membangun sistem budaya organisasi yang mungkin tidak ditemukan dalam pengelolaan sekolah sebelumnya. sebagaimana di beberapa wawancara yang dilakukan oleh Tim assasement IKIP Budi Utomo Malang kepada pihak pengelola 
sekolah dan Pondok di pesantren Bahrul Maghforah ini bahwa sistem koordinasi antar unit sekolah tidak berlangsung dengan baik, mulai dari polecy making yakni Yayasan, sampai manajemen sekolah dan unit-unit lainya seperti guru dan santri serta kordinatorkordinator lainya tidak terkoordinasi dengan baik. Disinilah salah satu kendala yang sampai hari ini membuat proses implementasi program integrasi kurikulum tidak berjalan sesuai harapan.

3. Menguatkan Sarana Dan Prasarana pendukung

Dalam hubunganya dengan penataan implementasi kurikulum terintegrasi, sekolah juga menyiapkan sarana dan prasarana yang mendukung, baik berhubungan dengan kesiapan penyesuaian atas konsepsi integrasi kurikulum yang dibangun, maupun pustaka pustaka relevan yang menjadi sumber rujukan dalam mennetukan materi materi yang diintegrasikan, serta kesiapan teknologi untuk mengimbangi proses pembelajaran di sekolah. Tentunya di dalam proses pembelajaran terdapat bebrapa kaidah serta komponen komponen yang membutuhkan perhitungan teknologi seperti dalam media pembelajaran ataupun teknologi pembelajaran yang secara husus akan membutuhkan kehadiran kesiapan teknologi di dalam proses pembelajaran di kelas.

Secara umum berkaitan dengan sarana dan prasarana pembelajaran di pondok tentunya masih sangat sederhana, namun beberapa materi tertentu sudah disediakan dengan cukup, seperti perpustakaan atau pustaka-pustaka relevan, laboratorium peternakan, lab perikanan, laboratorium kewirausahaan, dan tentu keagamaan yang secara otomatis akan mendukung berlangsungnya pengembangan spiritualitas santri baik dalam proses belajar maupun pembentukan karakter dan mental santri. Tentunya ketersediaan beberapa laboratorium di pondok yang demikian tersedia dengan baik ini bisa ikut membantu pengelolaan progran kurikulum terintegrasi. Dimana selain siswa atau santri dikuatkan secara materi dan pendekatan pendekatan keilmuan, santri juga dibekali liveskill atau ketrampilan tertentu yang sangat bermanfaat bagi masa depan atau lulusan sekolah Bahrul Maghfiroh.

\section{KESIMPULAN}

Sejak dilakukan marger kurikulum di tingkat pondok, tidak ada satu unit pun di pondok yang tidak mengalami kesulitan dalam merespon, melakukan penyesuaian penyesuaian, terutama kebijakan waktu yang dalam beberapa waktu ini telah dicoba diintegrasikan Pondok Bahrul Maghfiroh ini. Bisa dibayangkan waktu sekolah harus diakomodasikan dengan waktu atau jadwal yang sudah mapan dilakukan selama ini di pondok, sementara peserta sasarannya sama yaitu para santri dan penyesuaian penyesuaian yang lain seperti para ustad atau guru dan manajemen sekolah tentunya. Artinya bahwa penyesuaian waktu mestinya tidak sama sekali memberikan dampak bagi perkembangan apapun, yang terjadi justru memberatkan bagi sasaran sekolah, ketika tidak dilakukan penyesuaian penyesuaian di ranah integrasi materi pelajaran atau kurikulum yang sedang dibidik.

Integrasi kurikulum secara substantif yang dimaksud justru bukan terletak di ranah waktu, akan tetapi bagaimana melekatkan penguasaan materi materi agama dengan kontek pelajaran umum yang relevan, begitu juga bagaimana materi materi umum dapat dikontekstualisasikan dengan pelajaran pelajaran keagamaan, sehingga masing 
masing materi pelajaran saling memberi titik singgung satu dengan yang lainnya dan saling berkesinambungan. Pola yang demikian ini bukan suatu yang mudah dilakukan, akan tetapi harus ada pengkajian husus, workshop atau studi secara lebih inten terhadap konteks materi materi pelajaran yang sedang dan akan diintegrasikan. Harapannya santri atau siswa mendapatkan pemahaman yang kontekstual atas masing masing pelajaran yang ditempuh. Karena pemahaman yang tidak komprehensif dalam memahami konsep kurikulum terintegrasi ini akan mengalami kesulitan dan bahkan beban tersendiri, tidak saja bagi siswa ataupun guru, tetapi juga manajemen sekolah secara umum.

Untuk merespon pemahaman yang komprehensip di tingkat implementatif ini, di ranah manajemen sekolah harus terus melakukan kooordinasi koordinasi untuk menyamakan persepsi terhadap program marger atau integrasi kurikulum yang relatif baru ini, belum lagi jika akan di dekatkan lagi dengan UU pesantren. Setidaknya dilakukan monitoring dan evaluasi secara keseluruhan di setiap tahap implementasi, sehingga masing masing unit dapat memposisikan peran dan kontribusinya sesuai dengan mekanisme yang berlaku.

\section{Rekomendasi}

a. Kebijakan marger kurikulum tidak bisa digeneralisasi /digebyah uyah dengan menggunakan satu mekanisme operasional. Harus ada skala prioritas dan perlunya mapping pondok atau identifikasi sekolah. Sekolah yang mampu dan siap melakukan marger kurikulum harus didukung penuh, sedangkan yang belum siap harus diadvokasi dan dikawal dalam operasionalisasi program. b. Diperlukan sistem koordinasi secara periodik dan sistemik dengan menggunakan sistem area/zonasi tertentu. Agar perkembangan kebijakan terintegrasi dapat dimonitoring dan dievaluasi setiap saat. Selain mekanisme kontrol yang bersifat advokatif, juga diperlukan media konsultatif yang aktif.

c. Perlunya rekonseptualisasi sistem kurikulum terintegrasi ketika diterapkan di masing masing pondok, kerena masing masing pondok memilki kekuatan dan kelemahan yang sangat beragam. Kearifan pondok merupakan modal sosial atau sumberdaya bagi berlangsungnya program marger /integrasi kurikulum.

d. Integrasi kurikulum menekankan pada aspek materi pelajaran bukan sekedar pada aspek waktu. Pengintegrasian materi harus dilakaukan pengayaan dan sumber-sumber referensi yang cukup, karena referensi merupakan daya dukung fundamantal dalam keberlangsungan program kurikulum terintegrasi.

\section{DAFTAR PUSTAKA}

Abdullah, Amin, et al (2003) Menyatukan Kembali Ilmu-ilmu Agama dan Umum. Yogyakarta: IAIN Suka Press.

Abrar, Darul. 2020. Kurikulum Pesantren (Model Integrasi Pembelajaran Salaf Dan Khalaf), eepublish, 1agustus 2020

Azra, Azyumardi (1996). "Modernisasi Pendidikan Islam: Sistem dan Epistemologi Ilmu" makalah pada Seminar Internasional tentang "Modernisasi Pendidikan Islam: Sistem, Metodologi dan Materi”, dalam rangka Peringatan 70 tahun Pondok Modern Gontor di Gontor Ponorogo, 31 Agustus 1996. 
Bagir, Zainal Abidin, et al (2005). Integrasi Ilmu dan Agama; Interpretasi dan Aksi. Bandung: Mizan.

Collins, Gillian \& Hazel, Dixon (1991). Integrated Learning Planned Curriculum Units, Stage 3. Australia: Bookshelf Publishing Australia and Multimedia International (UK) Ltd.

Fogarty, Robin (1991). How to Integrate The Curricula. New York: IRI/Skylight Publishing. Inc.

Hakim, Lukman et. al.2020. Pendidikan Islam Integratif: Best Practice Integrasi Pendidikan Agama Islam dalam Kurikulum Pendidikan Tinggi, Gestalt Media

Hasan, S. Hamid (1988). Evaluasi Kurikulum. Jakarta: Depdikbud Dirjen Dikti, Proyek Pengembangan Lembaga Pendidikan Tinggi Kependidikan.

Kertanegara, Mulyadi (2005). Integrasi Ilmu, Sebuah Rekonstruksi Holistik. Jakarta: Arasy Mizan dan UIN Jakarta Press.

Kniep, Giselle O. et.al. (1995).“Curriculum Integration: An Expanded View of An Abused Idea."Journal of Curriculum and Supervision". Vo. 10 No. 3.

Maurer, Richard, E. Designing Interdisciplinary Curriculum in Middle, Junior High, and High Schools. Boston, London, Toronto, Sydney, Tokyo, Singapue: Allyn and Bacon.

Potret madrasah dalam media masa, Puslitbang Pendidikan Agama dan Keagamaan, Badan Litbang dan Diklat, Departemen Agama, 2006

Revitalisasi Madrasah 2006, Puslitbang Pendidikan Agama dan Keagamaan, Badan Litbang dan Diklat, Departemen Agama, 2006

Steenbrink, Karel A (1983). Pesantren, Madrasah, Sekolah. Jakarta: LP3ES,. 